\section{Lectures for Students in Secondary Schools}

WITH the view of stimulating interest in science and its contacts with everyday life among pupils in secondary schools, the British Science Guild has inaugurated a new series of lectures by eminent men of science to pupils from such girls' schools in London. The first of the series will be by Mr. C. C. Paterson, director of the Research Laboratories of the General Electrio Company, who will lecture on "The Electron Liberated: its Industrial Consequences". The lecture will be given to pupils from schools north of the Thames on Monday, March 25, at 5.0 p.m. in the Lecture Theatre of the Institution of Electrical Engineers, Victoria Embankment, London, W.C.2, and will be repeated to the group of schools south of the river on Wednesday, March 27, at the same hour.

\section{Memorial to Sir Edgeworth David}

Is order to ensure a memorial worthy of Sir Edgeworth David, the geologist and explorer, who died on August 28, 1934, a meeting has been held in Sydney which included representatives from the business, professional, scientific and academic life of the eity, and the following resolution was adopted : "In view of the great work done by Sir Edgeworth David for the science of geology and in view of the outstanding importance of his teaching, research, and contributions to geological knowledge as the first Professor of Geology in the University of Sydney, the Committee resolves (1) that a fund to be known as the David Memorial Fund be raised, that it be handed over to the University of Sydney, and that the income from it be applied in such manner as the Senate thinks will best aid in the advancement of the science of geology; and (2) that the Senate be requested to associate the name of Sir Edgeworth David permanently with the Chair of Geology." Further information can be obtained from the Honorary Treasurers, David Memorial Fund, Science House, Gloucester Street, Sydney.

\section{Announcements}

His Majesty the King has been graciously pleased to accord his patronage to the Institute of Chemistry of Great Britain and Ireland. The Institute, which was founded in October 1877, celebrates this year its charter jubilee, having been incorporated by royal charter granted by H.M. Queen Victoria in June 1885.

THE University of Toronto has awarded the Charles Mickle fellowship for 1935 jointly to Dr. Edward Mellanby and Mrs. May Mellanby. The fellowship is endowed under a bequest by the late Dr. W. J. Mickle, and is awarded annually "to that member of the medical profession who is considered by the Council of the Faculty of Medicine of the University of Toronto to have done most during the preceding ten years to advance sound knowledge of a practical kind in medical art or science".

Mr. H. J. Poowey, general secretary of the Society of Chemical Industry, who was the first student to go through a course of chemical engineering at a British university-Liverpool 1894-98-has been awarded the Osborne Reynolds medal for meritorious contribution to the progress of the Institution of Chemical Engineers. The medal, which was first awarded in 1928, is in honour of Prof. Osborne Reynolds (1842-1912), whose researches on heat transmission and the flow of liquids are extremely important to the chemical engineer.

IT is announced that the dates for the May and June soirées of the Royal Society have been altered to Friday, May 3 and Friday, June 14.

The German Röntgen Society has recently had a memorial tablet erected to Röntgen at Pontresina in the Engadine, where for more than forty years he spent his annual holiday.

AN exhibition of hygiene will be held in Strasbourg on April 6-22 to demonstrate scientific, administrative, industrial and commercial progress in the field of hygiene and sanitary technique, particularly as regards corporal hygiene, school hygiene, housing, elothing, diet and sport. Further information can be obtained from Services Administratifs, Hôtel de Ville, rue Brulée 9, Strasbourg.

THE Association of Special Libraries and Information Bureaux (ASLIB) is to hold its twelfth annual conference at St. John's College, Cambridge, during the week-end beginning Friday, September 20 . Particulars may be obtained from the Secretary of the Association, 16 Russell Square, London, W.C.1. Sir Richard Gregory has agreed to accept re-nomination as president of the Association for 1935-36.

ON the initiative of the Italian Society of Criminal Anthropology and Psychology, a meeting was recently held in Paris, attended by the Minister of Justice, numerous leaders of the French medical and legal professions, members of the French society of criminal prophylaxis and various foreign representatives, to discuss a proposal to found an international society of criminal anthropology and psychology. After acceptance of the proposal, it was agreed to hold the first congress of the society in Rome next October.

Applications are invited for the following appointments, on or before the dates mentioned:-An assistant secretary to the British Association-The Secretary, British Association, Burlington House, W.1 (March 11). A principal of the Barrow-inFurness Technical College-The Director of Education, Town Hall, Barrow-in-Furness (March 12). A probationer naturalist (male) on the scientific staff of the Fishery Board for Scotland-The Secretary, 101 George Street, Edinburgh, 2 (March 18). A reader in sociology at Bedford College-The Academic Registrar, University of London, S.W.7 (April 1). A William Prescott professor of the care of animals in the University of Liverpool-The Registrar (April $23)$. 